\title{
Economics of Gas-to-Liquids (GTL) Plants
}

\section{Ekwueme Stanley Toochukwu, Izuwa Nkemakolam Chinedu, Obibuike Ubanozie Julian, Kerunwa Anthony", Ohia Nnaemeka Princewill, Odo Jude Emeka, Obah Boniface}

Department of Petroleum Engineering, Federal University of Technology, Owerri, Nigeria

Email address:

stanleyekwueme@yahoo.com (E. S. Toochukwu), anthonykerunwa@rocketmail.com (K. Anthony)

${ }^{*}$ Corresponding author

\section{To cite this article:}

Ekwueme Stanley Toochukwu, Izuwa Nkemakolam Chinedu, Obibuike Ubanozie Julian, Kerunwa Anthony, Ohia Nnaemeka Princewill, Odo Jude Emeka, Obah Boniface. Analysis of the Economics of Gas-to-Liquids (GTL) Plants. Petroleum Science and Engineering. Vol. 3, No. 2, 2019, pp. 85-93. doi: 10.11648/j.pse.20190302.17

Received: October 21, 2019; Accepted: November 23, 2019; Published: December 13, 2019

\begin{abstract}
This work evaluates the economics of GTL plant using two synthesis gas methods. The first method called the base case utilizes oxygen as fuel for combustion of natural gas, while the proposed case uses steam $/ \mathrm{CO}_{2}$ instead of Oxygen. The aim is to ascertain a more economically viable GTL configuration for an optimal GTL process. The associated flare gas at Egbema production sites in the Niger Delta has been chosen as case study. The gas flowrate is 50MMscfd of raw natural gas which was pre-treated before being fed into the main GTL plant. The liquid yield result shows that the proposed method has a liquid yield of $5730 \mathrm{~b} / \mathrm{d}$ over the $5430 \mathrm{~b} / \mathrm{d}$ gotten from the base case representing an increase in product yield of $5.5 \%$. The economic analyses show a quicker pay-out time of 4.9 years from the proposed model compared to 5.9 years from the base case. Using the proposed method gave an annual cashflow increase of $20.9 \%$ and NPV increase of $59.7 \%$ at $10 \%$ discount rates. Also the DCF-ROR from the proposed method was $20.3 \%$ compared to $16.6 \%$ gotten from the base method. Thus the proposed method is more profitable in terms of NPV. The project is recommended for application in the Niger Delta stranded and remote gas locations that have before now been subjected to flaring.
\end{abstract}

Keywords: Gas-to-Liquid, Natural Gas, Monetization, Pressurization, Energy, Syngas Generation

\section{Introduction}

The basic problem of natural gas lies in its transportation and storage. Unlike oil which is liquid, natural gas takes the shape of its container; thus, special containers must be deployed for its transportation and storage. Because of the nature of gases, construction of these vessels are rather more costly than that of crude oil making natural gas technologies relatively more expensive. Manufacturers of gas technologies seek ways that natural gas can be conveniently phased to enable its easy transportation to user locations. Most times, the gas can be used in the new phase when there is a permanent chemical conversion step or regasified to gas phase before usage when the conversion process is only a temporal physical one. These conversions are mainly to liquid phase through refrigeration, pressurization or use of catalyst, or to solid states through very low temperature refrigeration relying on its dewpoint and hydrate formation characteristics. The technologies available for natural gas conversions are Liquefied natural gas (LNG) technologies, compressed natural gas (CNG) technologies, Gas-to-wire (GTW) technologies, Gas to hydrates (GTH) technologies, Gas to liquids (GTL) technologies, natural gas liquids (NGL) extraction technologies [1].

Gas-to-Liquids (GTL) technologies can offer adequate monetization of small associated gas volumes in scattered locations in the Niger Delta. These associated gases were flared before because they were not needed and as such were seen as nuisance, but now the emergence of gas projects have created a window for utilization of these gases. GTL presents one of the technologies for utilising these gases. A technological breakthrough in GTL technologies made available small-scale mini modular plants capable of handling small volumes of gases at a lower capital cost. Initially GTL was viewed as a capital intensive project requiring huge capital expenses and availability of large volume of gas for economic viability. Because of these constraints, only very few large scale commercial plant are 
operational [2-5]. The only plant in Nigeria is the Escravos GTL facility in Escravos Delta state. The project costs more than 5 billion dollars for its construction and expected to run at a capacity of $34000 \mathrm{~b} / \mathrm{d}$ of product fuels like diesel, gasoline etc. Economies of scale made available smaller plants for improve utilization of associated stranded gases [6]. A number of studies have attempted to evaluate the economic attractiveness of GTL technologies [7]. As is the case for any investment, four major parameters are used to determine the economic viability of GTL technology: i) Capital expenditures, ii) Feedstock costs, iii) Processing costs and iv) Product values.

Research has shown that among the various steps present in the GTL system, the syngas generation step is the most capital intensive. This is because of its high energy consumption, cost of construction and complexity of configuration as an additional unit. This paper evaluates the economics of GTL plant using two synthesis gas method- an autothermal reforming method and a newly proposed steam $/ \mathrm{CO}_{2}$ method [8].

The processes involved in GTL plant operations are divided into four main units given below: The natural gas pre-treatment units, the synthesis gas unit, the Fisher Tropsch unit, the product upgrading unit

These four main units in the GTL plants have their peculiar operations, processes, considerations and objectives. A full GTL plant process is an integration of these units and processes for a common goal. Each unit is peculiar and distinct from the other and is important to the overall integrated system [9]. The raw gas is pretreatment in the pretreatment unit to remove impurities such as acid gases and some entrained liquids (e.g. wateror heavier end hydrocarbon). The pretreatment depends on the volume of gas and the mole composition of the gas. In the synthesis gas unit, the treated gas composed almost entirely of methane is converted to synthesis gas. The synthesis gas is composed of hydrogen and carbon monoxide - a precursor for most petrochemical industries. The synthesis gas unit comprises the pre-reformer unit and the reformer unit. The several types of synthesis gas units available are: the steam methane reforming, the partial oxidation reforming, the autothermal reforming, the dry reforming $\left(\mathrm{CO}_{2}\right.$ reforming $)$ and steam $/ \mathrm{CO}_{2}$ reforming [10]. The pre-reformer cracks heavier hydrocarbons in the pre-treated natural gas stream before being sent to the reformer. Here all hydrocarbons heavier than methane are converted to methane or synthesis gas. The reformer converts the methane to synthesis gas. In the Fischer Trospch unit, the synthesis gas is reacted to form synthesis crude which is upgraded in the product upgrading unit $[11,12]$.

\section{Economics of GTL Plant}

Considering the economics of GTL plant, factors relating to the project economics are of interest. The factors affecting the viability of GTL are summarized below: i) Capital Investment, ii) Operating expenditures, iii) Crude oil price, iv) Natural gas price.

\subsection{Capital Investment}

The capital investment (CAPEX) for GTL plant comes from various units and represent the largest economic expenditure of the GTL plant. The capital investment for a GTL plants includes the following [13]:

(1) The cost of the equipment (Ce): This includes all the equipment to be used in the GTL facility and includes individual equipment from all the units in the GTL process plant. The various units start from the gas pretreatment stage down to the product work-up. But in most GTL operations, the pre-treatment stage is not usually part of the main GTL process operation, this is because the treatment of the gas is sub-contracted out to companies and treated gas is delivered on purchase to the GTL operators. Although in some situation, the operators may wish to accomplish the pre-treatment of the natural gas onsite as part of the GTL operation especially in large commercial plants.

(2) The installation cost (Ci): This includes the cost of installing the various equipment onsite. The sum of the total equipment cost and installation cost is called the inside battery limit cost (ISBL). The installation cost comprises the following operations: (a) Piping, (b) Electrical, (c) Equipment erection, (d) Instrumentation and control, (e) Civil works, (f) Structures and building, (g) Lagging and paint

(3) The outside battery limit cost (OSBL): This includes other costs such as the engineering and design, offsites, contingents.

(4) The working capital (Wc): The working capital is additional money needed in order to run the plant until the plant starts to earn income. The working capital is returned at the end of the project time. For petrochemical industries the working capital is typically $15 \%$ of fixed capital investment [14].

$$
\begin{gathered}
\text { ISBL }=C_{e}+C_{i} \\
\text { Total fixed cost }\left(T_{f c}\right)=I S B L+O S B L \\
\text { Total investment cost }=T_{f c}+W_{c}
\end{gathered}
$$

Total investment cost $(\mathrm{CAPEX})=C_{e}+C_{i}+O S B L+W_{c}$

\subsection{Equation for Estimation of CAPEX}

To address the plant capacity, economies of scale relate the CAPEX to the plant capacity and may be expressed in the equations below [15].

$$
\begin{aligned}
& \text { Cost Ratio }=(\text { Capacity Ratio })^{Y} \\
& \text { Cost }=\text { Base Cost } *\left[\frac{\text { Capacity }}{\text { Base capacity }}\right]^{Y} \\
& \text { Cost }=\text { constant } *(\text { Capacity })^{Y}
\end{aligned}
$$

Where Y reflects the degree to which a particular facility 
benefits from economies of scale. A value of 1.0 implies the facility does not benefit from economies of scale. For example, the construction of parallel trains (instead of larger ones) would yield $\mathrm{Y}$ values approaching 1.0. Y values for refining and petrochemical plant are typically 0.5 to 0.88 . The value for GTL plant is estimated at 0.66.

\subsection{The Operating/Production Cost Estimation}

These are costs which are dependent on production, such as electricity and operators. For the purpose of this work the natural gas cost is excluded from the operating cost. This is done for easy evaluation of the sensitivity of the project economics to changing natural gas price since the operating cost (OPEX) is given as a percentage of the CAPEX.

\subsection{Crude Oil Price}

The price of crude oil affects GTL product price. This is because GTL products compete with conventional crude oil products. If crude oil price is generally low, the cost of crude oil products will be low and it will affect the demand for GTL products. This is because GTL conversion technologies are generally capital intensive and can only thrive if crude oil price is high to justify investment.

\subsection{Natural Gas Price}

Natural gas price is one of the single factors that affect the total operating expenditure for a GTL project. The price of gas utilized as feedstock by GTL is usually negotiated between the host nation and the investor with little reference to market prices. Studies have shown that for a GTL project to be viable, the price of gas must not exceed \$0.5/MMBTU. IOCs who have partnered with producing nations on GTL projects may obtain preferential gas prices for their GTL facility. In some cases because the natural gas is flared, it can be given at no cost initially for a contract agreement to investors on agreement with host government in bid to develop the resource, monetize the gas and stop gas flaring in the country.

\section{Methodology}

The methodology comprises the economic indicators for the GTL plant. They are discussed and evaluated below.

\subsection{Economic Evaluation Variables}

The following economic evaluation variables shall be considered: The Payout time (POT), the discounted cash flow rate of return (DCF-ROR), the net cash flow, the net present value, Profit per investment ratio.

i). Cash Flow/NCR

The cash flow is calculated from the formula given below:

$$
C_{f}=\left\{\left(R_{a}-A_{t o c}-d_{a}\right) *\left(1-F_{i t}\right)\right\}+d_{a}
$$

Where $C_{f}=$ cashflow/NCR, $R_{a}=$ Annual Revenue in dollars, $A_{t o c}=$ Annual total production cost, $d_{a}=$ Annual depreciation, $F_{i t}=$ fractional income tax.

The taxable income $\left(T_{\text {in }}\right)$ is given by

$$
\left(T_{\text {in }}\right)=R_{a}-A_{\text {toc }}-d_{a}
$$

The depreciation used here is the straight-line depreciation method and is given by

$$
\text { Depreciation }=\frac{\text { Equipment cost-Salvage value }}{\text { Life period of Equipment }}
$$

The total annual operating cost is the total cost per year of the non-feedstock cost and the natural gas price.

ii). Payout Time (POT)

Mathematically the pay-out time is calculated as

$$
P O T=\frac{\text { Capital cost }}{\text { Cashflow } / N C R}
$$

iii). The Discounted Cashflow Rate of Return (DCF-ROR)

This is the discount rate at which the net present value is equal to zero.

iv). Net Present Value (NPV)

The following is the formula for calculating NPV

$$
N P V=\sum_{t=1}^{T} \frac{C_{t}}{(1+r)^{t}}-C_{0}
$$

Where: $\mathrm{C}_{\mathrm{t}}=$ net cash inflow during the period $\mathrm{t}, \mathrm{C}_{\mathrm{o}}=$ total initial investment costs, $r=$ discount rate, and, $t=$ number of time periods.

\subsection{Project Case Study}

The case study here describes the location under investigation. For this project, we consider the conversion and monetisation of the flare natural gas at Egbema production sites. This region has been heavily impacted by gas flaring. The construction of GTL facility in this area is expected to convert the flare gases into premium quality transport fuels like diesel, gasoline and kerosene for home usage. The GTL products are to be mostly utilized in the nearby Owerri, the capital city of the state while surplus will be sold to Portharcourt and Onitsha, the adjoining cities. Literature reveals that more than 50MMscfd of gas is being flared in this region. This volume becomes our target volume for monetisation. We employ mini modular technology because of the relatively small volume of the gas and to ensure project optimisation and private investor partnership. The project is expected to yield $5000 \mathrm{~b} / \mathrm{d}$ of GTL liquid fuels, this is the plant capacity.

To determine the capital cost of this $5000 \mathrm{~b} / \mathrm{d}$, plant we make comparison with existing mini GTL facilities currently in operation in other areas. For this project analysis we make use of the capital cost of CompactGTL facility at Kazakhstan. This facility has a capacity of $2500 \mathrm{~b} / \mathrm{d}$ of GTL liquid products with an overall capital cost of US\$275MM. from these we can calculate the capital cost of our proposed GTL plant using equation 6 .

From the calculation the total capital cost of our proposed plant is US\$434,522,721 which is approximated to be US\$434.5MM. The capital cost calculated includes all the 
units which also comprise the ASU plant for generation of oxygen. But since the ASU will be operated by independent licensed operators and oxygen sold to the GTL operators, we shall exclude the cost of ASU plant from the capital investment cost (CAPEX) of the GTL plant.

From literature conventional ATR plants with ASU has its ASU contributing about $20 \%$ of the total investment cost (CAPEX) of the overall process plant. If we subtract $20 \%$ from the estimated cost of the GTL, then the new GTL CAPEX without ASU plant will be US\$347,618,177, approximately US\$347.6MM. Thus, the capital cost of the ATR configuration for use in this work is US\$347.6MM.

\subsubsection{Base Case (Case 1)}

In this case, a GTL plant was designed using Autothermal reforming method as the method for the synthesis gas production. The synthesis gas here is the precursor to the actual Fischer Tropsch reaction. The Autothermal reformer (ATR) uses oxygen from air separation unit (ASU) as one of the reactants. Other reactants includes steam and the pretreated natural gas.

\subsubsection{Alternative Case (Proposed Method)}

Alternative case, we design a process plant that will minimize cost and enhance performance and less pollution. In this work we propose a method that is $\mathrm{CO}_{2}$ reductive, this method uses steam and $\mathrm{CO}_{2}$ as the reactant fuels instead of oxygen as in base case. Furthermore $\mathrm{CO}_{2}$ is supplied externally from the market to get the required amount necessary for the synthesis gas production.

\subsection{Project Economic Parameters}

The economic parametres for the project is given below.

i. Plant capacity is $5430 \mathrm{~b} / \mathrm{d}$ for ATR GTL plant and $5730 \mathrm{~b} / \mathrm{d}$ for steam/ $\mathrm{CO}_{2}$ GTL plant from natural gas inlet flowrate of 50MMscfd

ii. Capital cost is US\$347.6MM (ASU excluded)

iii. Feedstock cost is $\$ 2.5 / \mathrm{MMBTU}$ since gas is flared gas

iv. OPEX is $5 \%$ of CAPEX (excluding natural gas price and cost of $\mathrm{O}_{2}$ or $\mathrm{CO}_{2}$ )

v. Plant operational period of 25 years

vi. 350 plant operational days per year

vii. Refined GTL product price of $\$ 100 / \mathrm{bbl}$ for diesel and kerosene, $\$ 90 / \mathrm{bbl}$ for gasoline

viii. Straight line depreciation method

ix. Salvage value of zero

x. Income tax of $35 \%$ base case

\section{Result and Discussions}

Result of economic analyses are presented based on the total barrels of liquid products produced. The economic analyses are determined concurrently for the ATR reforming and for the steam $/ \mathrm{CO}_{2}$ reforming GTL plants.

\subsection{GTL plant Product Yield}

The GTL simulation yield is summarized in the table below.

Table 1. GTL plant product yield for ATR syngas method.

\begin{tabular}{lll}
\hline \multirow{2}{*}{ Component } & \multicolumn{2}{l}{ Volume (b/d) } \\
\cline { 2 - 3 } & ATR & Steam/CO2 \\
\hline Gasoline & 3025 & 3120 \\
Kerosene & 1380 & 1425 \\
Diesel & 1025 & 1185 \\
Total & 5430 & 5730 \\
\hline
\end{tabular}

From table 1 above, the product yield from the steam $/ \mathrm{CO}_{2}$ reforming is $5730 \mathrm{~b} / \mathrm{d}$ while that of the ATR method is $5430 \mathrm{~b} / \mathrm{d}$. For a rule of thumb the liquid product yield for GTL plant is 1 barrel for 10,000 scf of pre-treated natural gas feedstream. From this calculation our feedstream corresponds to a conventional production of $5000 \mathrm{~b} / \mathrm{d}$. Both the ATR reforming method and the steam/ $\mathrm{CO}_{2}$ reforming method gave high product yields. When compared with the expected yield from the rule of thumb, the product yield from the steam $/ \mathrm{CO}_{2}$ reforming method represents a $14.6 \%$ increase while the product yield from the ATR plant represents an $8.6 \%$ increase. Thus, the steam $/ \mathrm{CO}_{2}$ has more product yield and is preferred as a choice over the ATR reforming GTL plant method.

\subsection{Result for Revenue}

Revenue was calculated on annual basis. The annual revenue comprises the money accrued from the sales of the GTL product per year. The annual revenue calculation is presented in table 2 below.

Table 2. Revenue presentation for both cases of the GTL project.

\begin{tabular}{|c|c|c|c|c|c|c|c|}
\hline \multirow{2}{*}{ GTL Product } & \multirow{2}{*}{$\begin{array}{l}\text { Market Price } \\
\text { (US\$)/Bbl }\end{array}$} & \multicolumn{2}{|c|}{ Production Capacity (B/D) } & \multicolumn{2}{|c|}{ Total Daily Revenue (US\$) } & \multicolumn{2}{|c|}{ Total Annual Revenue (US\$) } \\
\hline & & ATR & Steam/ $\mathrm{CO}_{2}$ & ATR & Steam/ $\mathrm{CO}_{2}$ & ATR & Steam $/ \mathrm{CO}_{2}$ \\
\hline Gasoline & 90 & 3025 & 3120 & 272250 & 280800 & 95287500 & 98280000 \\
\hline Kerosene & 100 & 1380 & 1425 & 138000 & 142500 & 48300000 & 49875000 \\
\hline Diesel & 100 & 1025 & 1185 & 102500 & 118500 & 35875000 & 41475000 \\
\hline Total & - & 5430 & 5730 & 512750 & 541800 & 179462500 & 189630000 \\
\hline
\end{tabular}

From the table above, the annual revenue for ATR and steam $/ \mathrm{CO}_{2}$ reforming are US\$179462500 and US\$189630000 respectively. The revenue from the steam $/ \mathrm{CO}_{2}$ reforming of the GTL plant gave a $5.67 \%$ increase in revenue from that of the ATR, thus more revenue is realized from the use of steam/ $\mathrm{CO}_{2}$ reforming GTL plant than the ATR reforming GTL method.

\subsection{Result for OPEX of the GTL Plant}

The Operating expenses for the GTL project for both cases 
are presented in the table below. The table below gives the

result of the OPEX used in this work.

Table 3. Calculation of Total OPEX of the GTL project.

\begin{tabular}{lllll}
\hline \multirow{2}{*}{ Component } & Flowrate (MMscfd) & \multirow{2}{*}{ Cost per (Mscf) } & Annual cost (US\$) & STEAM/CO \\
\cline { 3 - 5 } & & 2.5 & 43750000 & 43750000 \\
\hline Natural gas & 50 & 2 & 35133000 & - \\
Oxygen & 50.19 & 1.5 & - & 26349750 \\
$\mathrm{CO}_{2}$ & 50.19 & - & 17380908.85 & 17380908.85 \\
Variable OPEX (5\% of CAPEX) & - & - & 78883000 & 70099750 \\
Total OPEX & - & & \\
\hline
\end{tabular}

From table 3 above, the total OPEX for the ATR and the steam $/ \mathrm{CO}_{2}$ reforming GTL plants are US\$78883000 and US\$70099750 respectively. There was a reduction of $11.13 \%$ in the OPEX from the use steam $/ \mathrm{CO}_{2}$ reforming technique for the GTL plant making the proposed method less costly to

\subsection{Result for Key Economic Indicators of the GTL Project}

Table 4 below gives the economic indicators of the project. Comparison is made for both cases. operate than the base case method.

Table 4. Presentation of Economic Indicators for the GTL project.

\begin{tabular}{llll}
\hline Economic Parameter & ATR & Steam/CO & Difference \\
\hline Annual Cashflow/NCR (Us\$) & 58945738.7 & 71263726 & $20.9 \%$ \\
NPV (Us\$) & 187434652 & 299245518 & $59.7 \%$ \\
DCF-ROR (\%) & 16.6 & 20.3 & 4.7 \\
Pay-Out Time, Pot (Yrs) & 5.9 & 4.9 & 1 \\
P/\$ & 3.24 & 4.13 & 0.89 \\
\hline
\end{tabular}

From table 4 above, it can be seen that using steam $/ \mathrm{CO}_{2}$ method for the reforming of the GTL improves the profitability in all the indices considered. There is a $59.7 \%$ difference in the NPV when steam $/ \mathrm{CO}_{2}$ method was chosen instead of the ATR for the GTL plant project. This amounts to a net profit of US\$111810866 from the use of steam $/ \mathrm{CO}_{2}$ reforming method.
The DCF-ROR for the GTL project for US\$2.5/Mscf natural gas price are $16.6 \%$ and $20.3 \%$ respectively while the Pay-out time are 5.9 years and 4.9 years for the ATR and steam $/ \mathrm{CO}_{2}$ reforming method respectively. The figure 1 below gives the POT and the DCFROR for both cases considered.

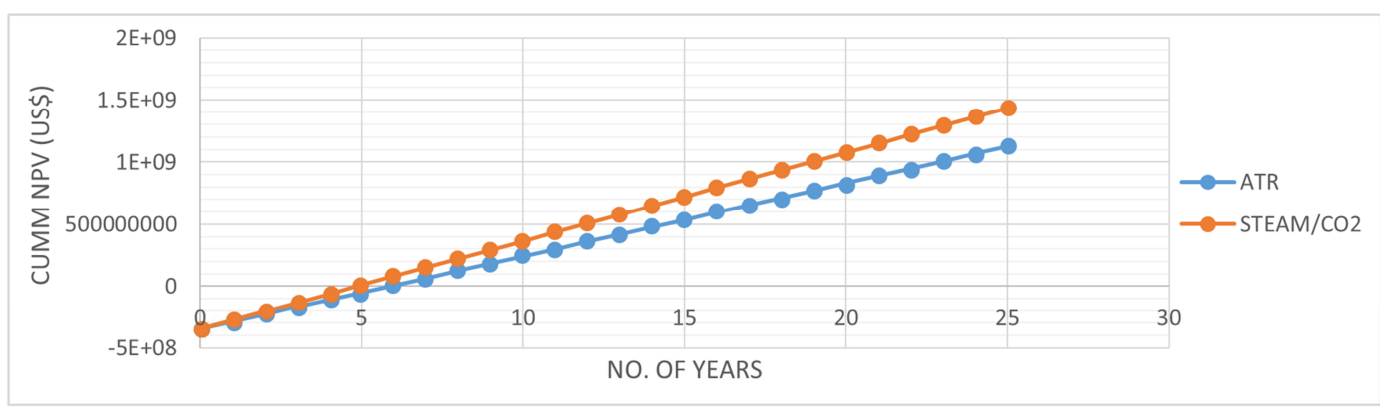

Figure 1. Figure showing Pay-Out Time for US\$2.5/Mscf natural gas price for both cases of the GTL plant considered.

From figure 1, it can be seen that using steam/ $\mathrm{CO}_{2}$ reforming gives a faster pay-out time than the ATR method for the synthesis gas production during GTL plant operation.

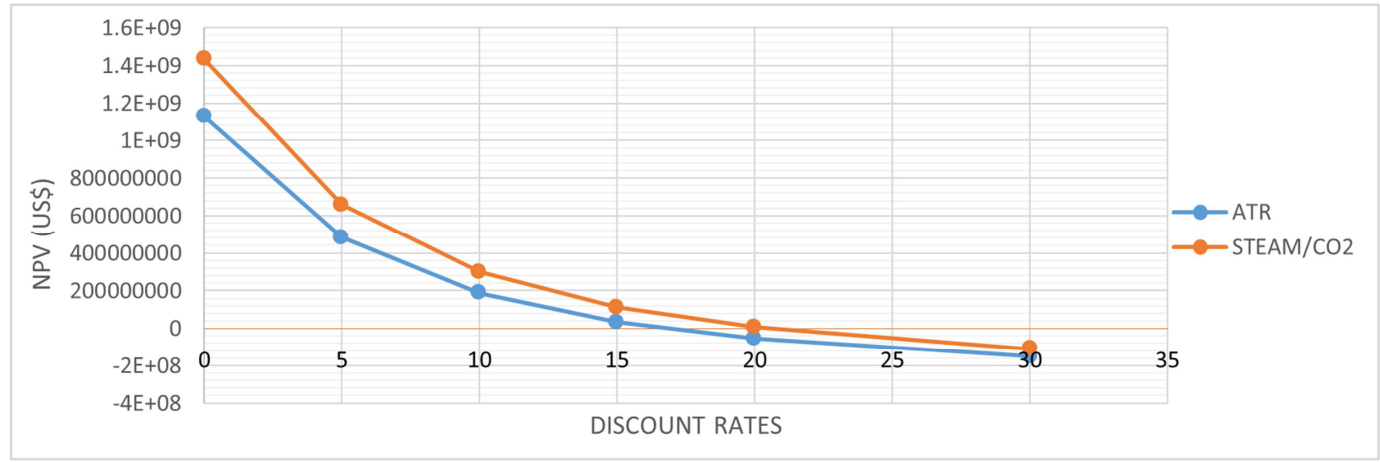

Figure 2. DCF-ROR for the project natural gas price of US\$2.5/Mscf. 
The discounted cashflow rate of return is the discount rate that will yield an NPV of zero. From figure 2 above, the DCF-ROR is $16.6 \%$ for ATR reforming GTL method and $20.3 \%$ for steam $/ \mathrm{CO}_{2}$ reforming GTL method. The DCFROR of $16.6 \%$ and $20.3 \%$ calculated shows that the project is economically viable for the two cases considered since the discount rates for most gas projects are not greater than $10 \%$. Despite that, the steam $/ \mathrm{CO}_{2}$ is more preferable when considering the DCF-ROR because it gave a higher value at the economic prevalent considered.

\subsection{Sensitivity Analyses}

Sensitivity analyses are performed on both cases to ascertain the sensitiveness of economic variables on economic performance indices. This is done by changing some factors while others are kept constant to determine the baseline of profitably of the project under changing economic conditions in the future. The sensitivity was conducted with changes in the following factors: i) Discount rates of $10 \%, 15 \%$ and $20 \%$ are used, ii) Natural gas cost of US $\$ 2.5 / \mathrm{Mscf}$ and US $\$ 3 / \mathrm{Mscf}$, iii) Changes in non-feed stock OPEX of $5 \%$ and $6 \%$, iv) Changes in CAPEX of US\$80,000 PBLD and US\$100,000 PBLD.

\subsection{Sensitivity Analyses of the ATR Reformer GTL Plant}

For the ATR reforming method, the total product yield is $5430 \mathrm{~b} / \mathrm{d}$. The capital cost per barrel liquid a day (PBLD) is US\$64018 PBLD. Thus, we evaluate the sensitivities for US\$80,000PBLD and US\$100,000PBLD. The table below gives the sensitivity analyses of the ATR reformer for natural gas price of US2.5/Mscf and for changes in CAPEX to following values: US\$80,000PBLD and US\$100,000PBLD

\subsubsection{Sensitivity ATR Reformer for Natural Gas Price of US\$2.5/Mscf}

Table 5 below describes the results for sensitivity analyses of the GTL project for natural gas price of US\$2.5/Mscf.

Table 5. General economic indices for sensitivity analyses of ATR reformer GTL plant at natural gas price of US\$2.5/Mscf.

\begin{tabular}{|c|c|c|c|c|c|c|}
\hline \multirow{3}{*}{$\begin{array}{l}\text { ATR: NG price } \\
\text { US\$2.5/Mscf } \\
\text { Discount Rates }\end{array}$} & \multirow{2}{*}{\multicolumn{2}{|c|}{$\begin{array}{l}\text { CAPEX: \$50,000/BLPD } \\
\text { OPEX }(\% \text { OF CAPEX) }\end{array}$}} & \multicolumn{2}{|c|}{ CAPEX: \$64,018/BLPD } & \multicolumn{2}{|c|}{ CAPEX: $\$ 80,000 / B L P D$} \\
\hline & & & \multirow[b]{2}{*}{$5 \%$} & \multirow[b]{2}{*}{$6 \%$} & \multirow[b]{2}{*}{$5 \%$} & \multirow[b]{2}{*}{$6 \%$} \\
\hline & $5 \%$ & $6 \%$ & & & & \\
\hline $10 \%$ & 276334992 & 260316286 & 187434652 & 166924916 & 86079971 & 60450041 \\
\hline $15 \%$ & 118636769 & 107229162 & 33415866 & 18810004 & -63743914 & -81996085 \\
\hline $20 \%$ & 27106296 & 18375042 & -55979005 & -67158168 & -150704000 & -164674006 \\
\hline NCR & 60353925 & 58589175 & 58945739 & 56686221 & 57340275 & 54516675 \\
\hline DCF-ROR & 21.4 & 21.4 & 16.6 & 15.9 & 12.5 & 11.8 \\
\hline POT & 4.63 & 4.63 & 5.9 & 6.13 & 7.58 & 7.97 \\
\hline
\end{tabular}

From table 5, it can be seen that the NPV decreases as the CAPEX is increased. The CAPEX is a factor that largely affects the NPV as shown in the figure 3 below.

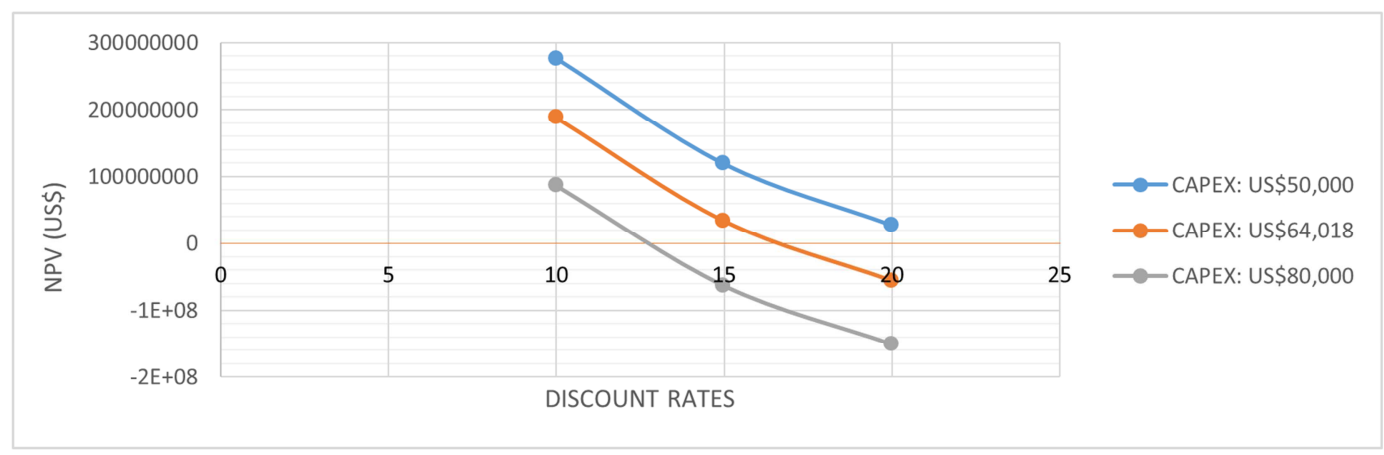

Figure 3. Graph of NPV vs. time for the ATR reforming at natural gas price of US\$2.5/Mscf.

Furthermore, we investigate the economic sensitivity of the project when the natural gas price increases from US\$2.5/Mscf to US\$3.0/Mscf. The table 6 below gives the economic variables.

\subsubsection{Sensitivity ATR Reformer for Natural Gas Price of US\$3/Mscf}

Table 6 below describes the results for sensitivity analyses of the GTL project for natural gas price of US\$3/Mscf

Table 6. General economic indices for sensitivity analyses of ATR reformer GTL plant at natural gas price of US\$3.0/Mscf.

\begin{tabular}{|c|c|c|c|c|c|c|}
\hline \multirow{2}{*}{$\begin{array}{l}\text { ATR: NG price } \\
\text { US\$3.0/Mscf }\end{array}$} & \multicolumn{2}{|c|}{ CAPEX: $\$ 50,000 / B L P D$} & \multicolumn{2}{|c|}{ CAPEX: $\$ 64,018 /$ BLPD } & \multicolumn{2}{|c|}{ CAPEX: $\$ 80,000 / B L P D$} \\
\hline & \multicolumn{6}{|c|}{ OPEX (\% OF CAPEX) } \\
\hline Discount Rates & $5 \%$ & $6 \%$ & $5 \%$ & $6 \%$ & $5 \%$ & $6 \%$ \\
\hline $10 \%$ & 224709327 & 208690621 & 135808987 & 115299251 & 34454305 & 8824376 \\
\hline $15 \%$ & 81871921 & 70464314 & -3348982 & -17954844 & -100508762 & -118760933 \\
\hline $20 \%$ & -1033105 & -9764359 & -84118406 & -95297569 & -178843401 & -192813408 \\
\hline
\end{tabular}




\begin{tabular}{|c|c|c|c|c|c|c|}
\hline \multirow{2}{*}{$\begin{array}{l}\text { ATR: NG price } \\
\text { US\$3.0/Mscf }\end{array}$} & \multicolumn{2}{|c|}{ CAPEX: $\$ 50,000 / B L P D$} & \multicolumn{2}{|c|}{ CAPEX: $\$ 64,018 / B L P D$} & \multicolumn{2}{|c|}{ CAPEX: $\$ 80,000 / B L P D$} \\
\hline & \multicolumn{6}{|c|}{ OPEX (\% OF CAPEX) } \\
\hline Discount Rates & $5 \%$ & $6 \%$ & $5 \%$ & $6 \%$ & $5 \%$ & $6 \%$ \\
\hline NCR & 5466425 & 52901675 & 53258239 & 50998721 & 51652775 & 48829175 \\
\hline DCF-ROR & 19.9 & 19.2 & 14.8 & 14.1 & 11 & 10.3 \\
\hline POT & 4.97 & 5.13 & 6.53 & 6.8 & 8.41 & 4.97 \\
\hline
\end{tabular}

If the cost of natural gas is increased, the profitability of the project reduces. An increase of natural gas price by US\$0.5/Mscf gives a 0.36 year increase in pay-out time and a $1.5 \%$ decrease in the DCF-ROR for the ATR reforming of the GTL plant.

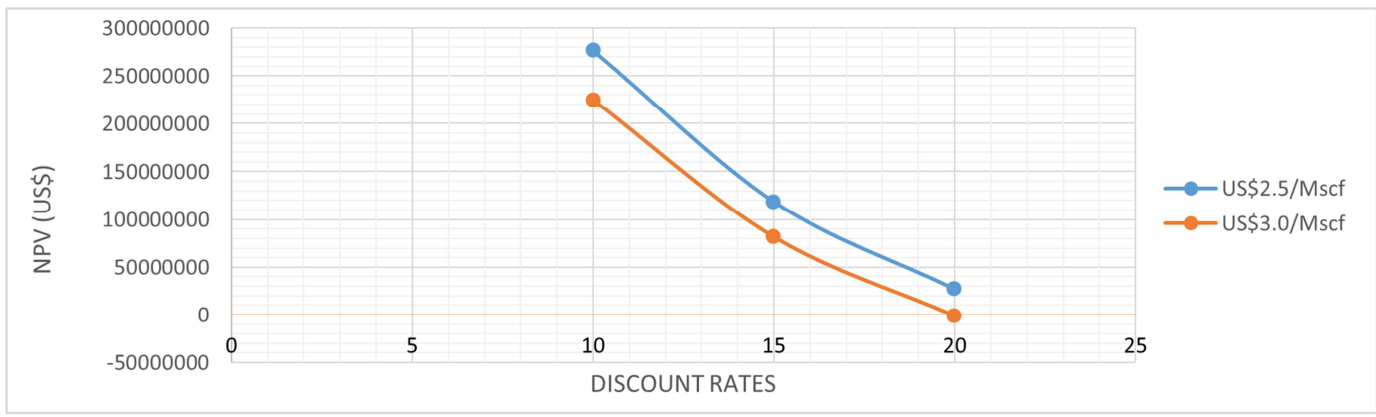

Figure 4. Graph of NPV vs. Discount Rates for the ATR reforming at natural gas price of US\$3.0/Mscf.

\subsection{Sensitivity for the Steam/CO $\mathrm{O}_{2}$ Reformer GTL Plant}

Here, we analyze the sensitivity of the economic variables on the economic performance of the GTL plant for the steam $/ \mathrm{CO}_{2}$ reformer. First, we evaluate for natural gas price of US\$2.5/Mscf and then for natural gas price of
US\$3.0/Mscf. The table below gives the result.

\subsubsection{Sensitivity for Natural Gas Price of US\$2.5/Mscf}

Table 7 below describes the result for sensitivity analyses of the GTL project for natural gas price of US\$2.5/Mscf

Table 7. General Economic Indices for Sensitivity Analyses of ATR Reformer GTL Plant at Natural Gas Price of US\$2.5/Mscf.

\begin{tabular}{|c|c|c|c|c|c|c|}
\hline \multirow{3}{*}{$\begin{array}{l}\text { Steam/ } / \mathrm{CO}_{2}: \mathrm{NG} \\
\text { price US\$2.5/Mscf } \\
\text { Discount rates }\end{array}$} & \multirow{2}{*}{\multicolumn{2}{|c|}{$\begin{array}{l}\text { CAPEX: \$50,000/BLPD } \\
\text { OPEX (\% OF CAPEX) }\end{array}$}} & \multicolumn{2}{|c|}{ CAPEX: \$64,018/BLPD } & \multicolumn{2}{|c|}{ CAPEX: \$80,000/BLPD } \\
\hline & & & \multirow[b]{2}{*}{$5 \%$} & \multirow[b]{2}{*}{$6 \%$} & \multirow[b]{2}{*}{$5 \%$} & \multirow[b]{2}{*}{$6 \%$} \\
\hline & $5 \%$ & $6 \%$ & & & & \\
\hline $10 \%$ & 388145858 & 372127152 & 299245518 & 278735781 & 197890836 & 172260906 \\
\hline $15 \%$ & 198262077 & 186854470 & 113041174 & 98435312 & 15881394 & -2370778 \\
\hline $20 \%$ & 88050611 & 79319357 & 4965310 & -6213853 & -89759685 & -103729691 \\
\hline NCR & 72671913 & 70907163 & 71263726 & 69004208 & 69658263 & 66834663 \\
\hline POT & 3.74 & 3.83 & 4.9 & 5.04 & 6.24 & 6.5 \\
\hline
\end{tabular}

Table 7 gives the economic performance indices for the steam $/ \mathrm{CO}_{2}$ reforming method of the GTL plant for natural gas price of US\$2.5/Mscf. From the table, it can be seen that the steam $/ \mathrm{CO}_{2}$ reforming process shows better pay-out time and DCF-ROR than that of the ATR.
At $20 \%$ discount rate the project is profitable for CAPEX of US\$50,000 PBLD and US\$64,018 PBLD. The figure below illustrates the relationship of the NPV with the discount rates for steam $/ \mathrm{CO}_{2}$ reforming at natural gas price of US\$2.5/Mscf.

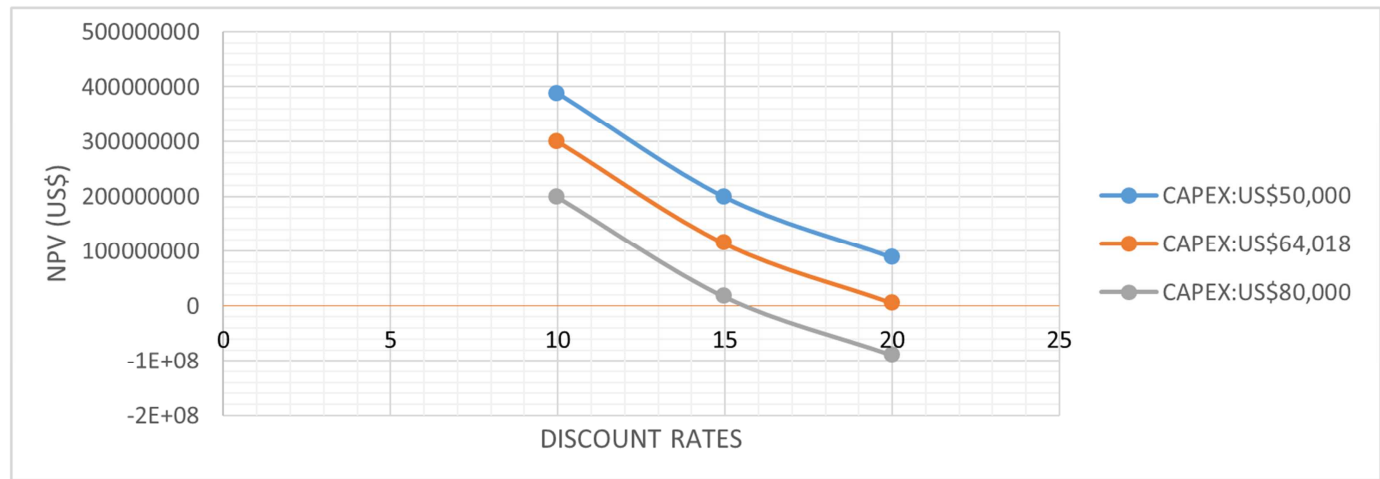

Figure 5. Graph of NPV vs. time for the steam/CO2 reforming at natural gas price of US\$2.5/Mscf. 
For natural gas price of US\$3.0/Mscf, the table below gives the effect of sensitivity on the economic performance of the project.

\subsubsection{Sensitivity for Natural Gas Price of US\$3/Mscf}

Table 8 below describes the result for sensitivity analyses of the GTL project for natural gas price of US\$3/Mscf.

Table 8. General Economic Indices for Sensitivity Analyses of ATR Reformer GTL Plant at Natural Gas Price of US\$3/Mscf.

\begin{tabular}{|c|c|c|c|c|c|c|}
\hline \multirow{2}{*}{$\begin{array}{l}\text { Steam/CO}: ~ \\
\text { price } \mathrm{US} \$ 3.0 / \mathrm{Mscf}\end{array}$} & \multicolumn{2}{|c|}{ CAPEX: \$50,000/BLPD } & \multicolumn{2}{|c|}{ CAPEX: $\$ 64,018 /$ BLPD } & \multicolumn{2}{|c|}{ CAPEX: \$80,000/BLPD } \\
\hline & \multicolumn{6}{|c|}{ OPEX (\% OF CAPEX) } \\
\hline Discount rates & $5 \%$ & $6 \%$ & $5 \%$ & $6 \%$ & $5 \%$ & $6 \%$ \\
\hline $10 \%$ & 336520193 & 320501486 & 247619853 & 227110116 & 146265171 & 120635241 \\
\hline $15 \%$ & 161497229 & 150089622 & 76276326 & 61670464 & -20883454 & -39135625 \\
\hline $20 \%$ & 59911210 & 51179956 & -23174091 & -34353254 & -117899086 & -131869093 \\
\hline NCR & 66984413 & 65219663 & 65576226 & 63316708 & 63970763 & 61147163 \\
\hline DCF-ROR & 24.6 & 23.9 & 18.6 & 17.9 & 14.2 & 13.5 \\
\hline POT & 4.05 & 4.16 & 5.3 & 5.49 & 6.79 & 7.1 \\
\hline
\end{tabular}

Increasing the natural gas price from $\$ 2.5 / \mathrm{Mscf}$ to $\$ 3 / \mathrm{Mscf}$ increases the pay-out time by 0.21 years and reduces the DCF-ROR by $2.1 \%$ for the seam/ $\mathrm{CO}_{2}$ reforming method of the GTL plant operation.

From the sensitivity analyses, natural gas price greatly affects the profitability of the GTL project. A natural gas price difference of US $\$ 0.5 / \mathrm{Mscf}$ led to a 0.36 year increase in pay-out time and a $1.5 \%$ decrease in the DCF-ROR for the ATR reforming of the GTL plant, also 0.4 years increase in pay-out time and $1.7 \%$ decrease in DCF-ROR for the proposed steam $/ \mathrm{CO}_{2}$ reforming method

\section{Conclusion}

Gas to liquids technology has been evaluated economically. Two methods were considered. The difference in configuration of the GTL plant in the two methods was in the synthesis gas unit. The synthesis gas unit for the base case was retrofitted with oxygen gas as fuel for the combustion of the natural gas coming into the GTL system while the alternative case used steam $/ \mathrm{CO}_{2}$ mixture instead of oxygen gas. The economic evaluation first of all shows that regardless of the synthesis gas method used above, the GTL process was an economical project under normal economic conditions and can compete favorably with other gas conversation methods like LNG.

Furthermore, from the evaluation it is seen that the steam $/ \mathrm{CO}_{2}$ method which is the proposed method for GTL plant operation has better economic performance than the autothermal reforming method. The plant yield for the proposed case is $5730 \mathrm{~b} / \mathrm{d}$ while the plant yield for the ATR was $5430 \mathrm{~b} / \mathrm{d}$ a difference of $300 \mathrm{~b} / \mathrm{d}$. the proposed case have also economically performed better than the ATR method in terms of NCR, NPV, DCF-ROR, POT and P/\$ making it more economically justifiable. The proposed method is therefore recommended as the GTL plant configuration method for small scale monetisation of the vast stranded flare associated gases in the Niger Delta.

\section{Nomenclature}

ASU: Air Separation Unit ATR: Autothermal Reformer b/d: barrels per day

CAPEX: Capital Expenditure

CNG: Compressed Natural Gas

$\mathrm{CO}_{2}$ : Carbondioxide

DCF-ROR: Discounted Cashflow Rate of Return

GTL: Gas-to-Liquids Technology

GtW: Gas-to-Wire

IOCs: International Oil Companies

ISBL: Inside Battery Limit Costs

LNG: Liquefied Natural gas

MMbtu: Million British thermal unit

MMscfd: Million standard cubic feet per day

Mscf: Thousand standard Cubic Feet

MTG: Methanol-to-Gasoline

NCR: Net Cash Recovery

NGL: Natural Gas Liquids

NPV: Net Present Value

OPEX: Operating Expenditure

OSBL: Outside Battery Limit Costs

P/\$: Profit-Per-Dollar Invested

$\mathrm{P} /$ : Profit-per-dollar Invested

PBLD: per Barrel-Liquid a Day

POT: Pay-Out-Time

STG: Syngas-to-Gasoline Plus

US\$: US dollars

\section{References}

[1] Wood, D. A., C. Nwaoha and B. F. Towler (2012). "Gas-toliquids (GTL): A review of an industry offering several routes for monetizing natural gas," Journal of Natural Gas Science and Engineering, Vol. 9, November.

[2] Enyi, C. G, Nagib, M., Nasr, G. G. (2011). A new Approach to effluent treatment in Gas-to-liquid (GTL). A paper prepared for presentation at the international petroleum technology conference held in Bangkok Thailand.

[3] Garrouch A. A. (2007). Economic Viability of Gas-to-Liquids Technology. Paper SPE 107274 presented at the SPE hydrocarbon economics and evaluation symposium, Dallas, Texas.

[4] Seddon, D. (2004). Why is GTL So Expensive? Paper SPE 88632 presented at the SPE Asia pacific oil and gas conference and exhibition, Perth, Australia. 
[5] Ekejiuba, A. I. B., 2017. Real-Time Monetization of the Flare Associated Stranded Natural Gas in Nigeria: Quantitative Analysis and Qualitative Values. The International Journal of Science \& Technology, Vol. 5 Issue 8, pp. 154.

[6] Taylor, M and Martin, P. (2004). Recent developments and technologies for cost effective gas monetisation. Advantica, Ashby road Loughborough, LE11 3GR, UK.

[7] Spath, P. L. and D. C. Dayton. (2003) "Preliminary screening-technical and economic assessment of synthesis gas to fuels and chemicals with emphasis on the potential for biomass-derived syngas," National Renewable Energy Laboratory, Golden, Colorado.

[8] Bello H., Joel, O., Ikiensikimema S. S (2012). Improving the efficiency of Fisher Tropsch Synthesis using the $\mathrm{CO}_{2}$ reduction Alternative. SPE paper prepared for presentation at the SPE international technical conference and Exhibition held in Abuja, Nigeria.

[9] Vosloo A. C (2000). Conceptual Design of Fisher Trospch based GTL plant. Sasol Technology Research and Development, Sasolburg, South Africa.
[10] Knutsen K. T. (2013). Modelling and optimization of a Gasto-Liquid plant. Master's degree thesis, Department of Chemical Engineering, Norwegian University of science and technology.

[11] Christiansen Lars J Rostrup-Nielsen Jens. (2011) Concepts in Syngas Manufacture. Imperial College Press.

[12] Hillestad, M. \&Rafiee A. (2010). Optimal design and operation of a gas-to-liquid process. Chemical Engineering Transactions, 21: 1393-1398.

[13] Nordvåg Ole Kristian (2012). Modelling and optimization of a Gas-to-Liquid plant. Department of Chemical Engineering, Norwegian University of Science and Technology.

[14] Sinnot, R; Towler, G. Chemical Engineering Design. Oxford: Elsevier Ltd., 2009.

[15] Al-Saadoon (2007). Economics of GTL plants. Paper presented at the SPE hydrocarbon Economics and Evaluation symposium, Dallas. 